\title{
APPLICATION OF SOME SELECTED YEASTS ISOLATES IN BIOELECTRICITY GENERATION USING MICROBIAL FUEL CELL (MFC)
}

\author{
ADEKANLE MARGARET. A., JULIUS K. OLOKE, ADEKUNLE O. CATHERINE AND ADESIJI Y. OLUWAKEMI
}

(Received 17 June 2020; Revision Accepted 29 August 2020)

\begin{abstract}
Power supply has remained a challeng issue in developing coutries. The aim of this study was to evaluate the potentials of selected yeast species for bioelectricity generation. Different yeast species were isolated from cassava wastewater, whey wastewater, human urine, and rabbit dung using the spread plate method. These isolates were identified using analytical profile index (API). Results obtained revealed the identity of the isolated yeast species as Candida famata, Candida hellenical. Candida tropicalis and Saccharomyces cerevisia (using API method). The isolated yeast species were used singly, and as a consortium for bioelectricity generation, and yeast in continuous mode. The same wastes as used for the isolation process were evaluated as possible substrates for the generation of bioelectricity. Out of the four wastes used, cassava processing wastewater gave the highest bioelectricity potential and was subsequently used as substrate for further study. Saccharomyces cerevisiae elicited the highest electricity generation when the four yeast species were used singly $(1.08 \mathrm{~V})$. A consortium of the four isolates elicited a synergis effect, generating $1.57 \mathrm{~V}$ of voltage. Stacking of the Microbial Fuel Cell(MFC) components improved voltage to $2.4 \mathrm{~V}$ due to its lower internal resistance within the stacked materials. It is apparent from the results obtained in this study that when properly harnessed, microbial fuel cells (MFCs) technology could serve as alternate source of renewable energy.
\end{abstract}

KEYWORDS: Microbial fuel cells, Waste, yeasts, Salt- Bridge, Nafion117.

\section{INTRODUCTION}

Microbial fuel cells (MFCs) have come a long way since the early $20^{\text {th }}$ century because the continuing use of petroleum fuel is now widely recognized as unsustainable, owing to their depleting supplies and its contribution to the accumulation of carbon dioxide in the environment. A microbial fuel cell (MFC) is a bioreactor that converts chemical energy present in the organic compounds (in the form of chemical bonds) to electrical energy through catalytic reactions of microorganisms under anaerobic conditions (Logan et al., 2012) Most microbial fuel cell development focused on bacterial cells as the biocatalyst and many reports are available on their construction, function and performance (Logan et al., 2006; Davis and Higson, 2007; Logan, 2009).
Reports on microbial fuel cells that use eukaryote cells are however rare in the literature. Yeasts microbial fuel cells have received little attention to date (Haslett,2012) although, the yeast should be ideal MFC catalyst because of their peculiar characters in that they are robust, easily handled and mostly non-pathogenic with high catabolic rates and in some case a broad substrate spectrum, which is environment friendly and regarded as a renewable energy source (Huang, 2008). At present, microbial fuel technology is not yet sufficiently developed to produce substantial quantities of power cost-effective manner (Huang, 2008). However, in this study, yeasts isolated from wastes were used to generate energy in a microbial fuel cell. This study was aimed to evaluate the bioelectricity generation of some selected yeast isolates from waste.

Adekanle Margaret. A., Pure and Applied Biology Department, Faculty of Pure and Applied Sciences, Ladoke AKintola University of Technology, Ogbomoso. Oyo State . Nigeria.

Julius K. Oloke, Pure and Applied Biology Department, Faculty of Pure and Applied Sciences, Ladoke AKintola University of Technology, Ogbomoso. Oyo State . Nigeria.

Adekunle O. Catherine, Pure and Applied Biology Department, Faculty of Pure and Applied Sciences, Ladoke AKintola University of Technology, Ogbomoso. Oyo State . Nigeria.

Adesiji Y. Oluwakemi, Department of Medical Microbiology \& Parasitology, Ladoke AKintola University of Technology Nigeria. 


\section{MATERIALS AND METHODS}

\section{Preparation of yeast isolates}

Different wastes were gathered from different locations in Osogbo and its environs such as cassava processing water from local factory at Ofatedo, whey processing water from Fulani community at Ido-Osun, human urine from a voluntary donor and Rabbit dung from a University animal house. The first three wastes were put in $10 \mathrm{ml}$ sterile bottles while 1gram of Rabbit dung was dissolved in $10 \mathrm{ml}$ sterile water; after which serial dilution was made to $10^{-7}, 0.5 \mathrm{ml}$ each were inoculated into Potato dextrose broth and incubated at $37^{\circ} \mathrm{C}$ for 24 hours. Potato dextrose agar plate (PDA) was prepared with gentamicin to inhibit any bacterial growth but favor the growth of yeast, and the overnight broth in the incubator was then streaked on different PDA plates and incubated at $37^{\circ} \mathrm{C}$ for 24 hours.

\section{Fabrication of 2 types of Chambers with Salt bridge and Nafion 117 as (PEM)}

In the microbial fuel chamber constructed, a proton exchange membrane (salt bridge) was used to link the two $250 \mathrm{ml}$ bottles subunits together by using PVC in the first design (Plate 1). For the second design, two $100 \mathrm{ml}$ bottles were connected with Nafion 117 (proton exchange membrane) instead of salt-bridge used in the first design (Plate 2). The proton exchange membrane (Nafion 117) was pre-treated before being used. It was boiled in 30\% hydrogen peroxide, washed in de-ionized water and $0.5 \mathrm{M} \mathrm{H}_{2} \mathrm{So}_{4}$ and stored in de-ionized water until used. The electrodes used in this design were metallic plates. The electrodes in the two subunits were connected with copper wire, then joined to a resistor $(500 \Omega)$ to complete the circuit. Anaerobic condition is required at the anode and so paper tape or plaster was used to wrap the lid in order to create that condition. The aerobic environment required at the cathode was created by not covering the opening at the lid of the cathode

subunit.

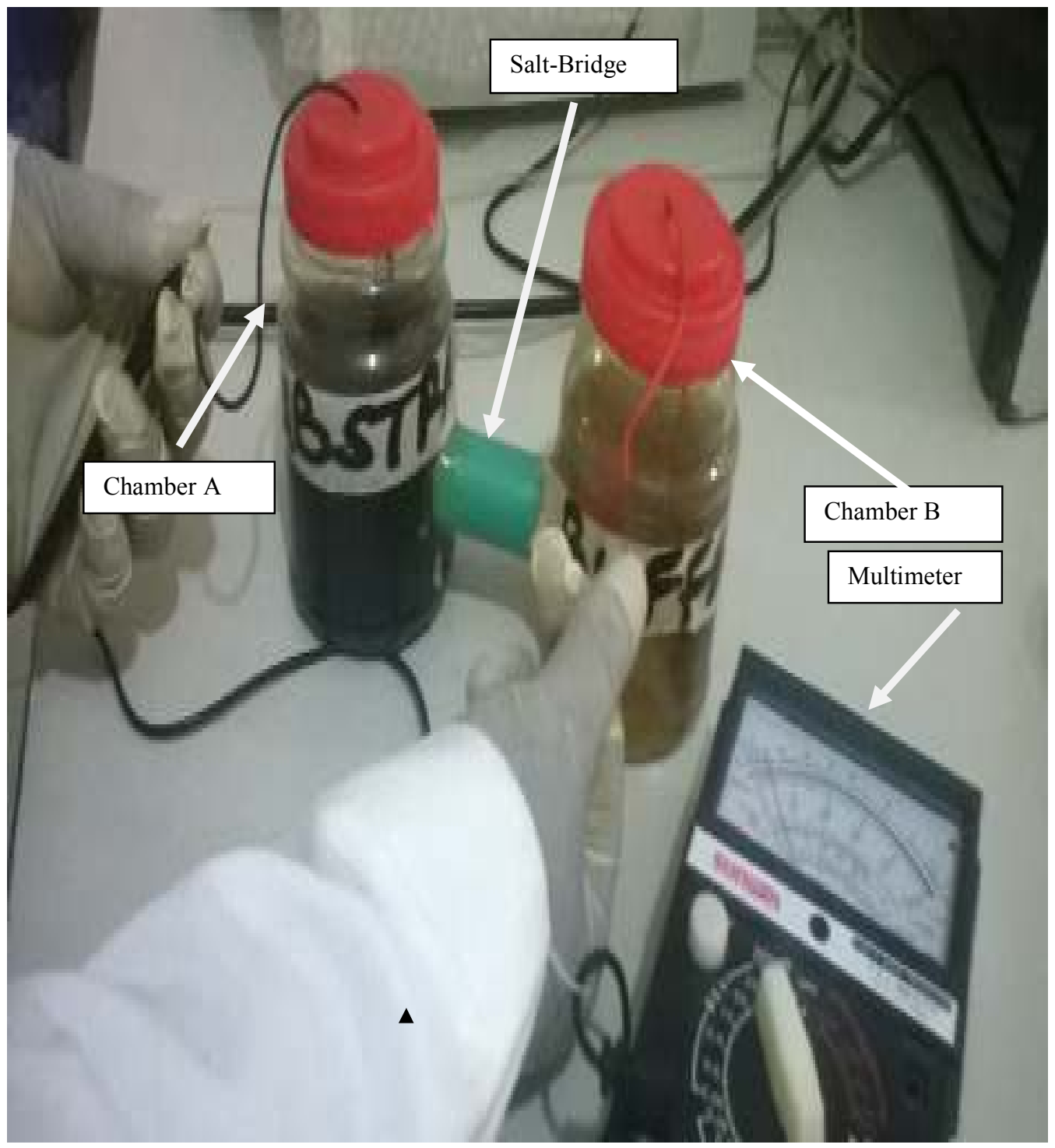

Plate 1: Two Chamber Microbial Fuel Cell design separated by Salt-bridge 


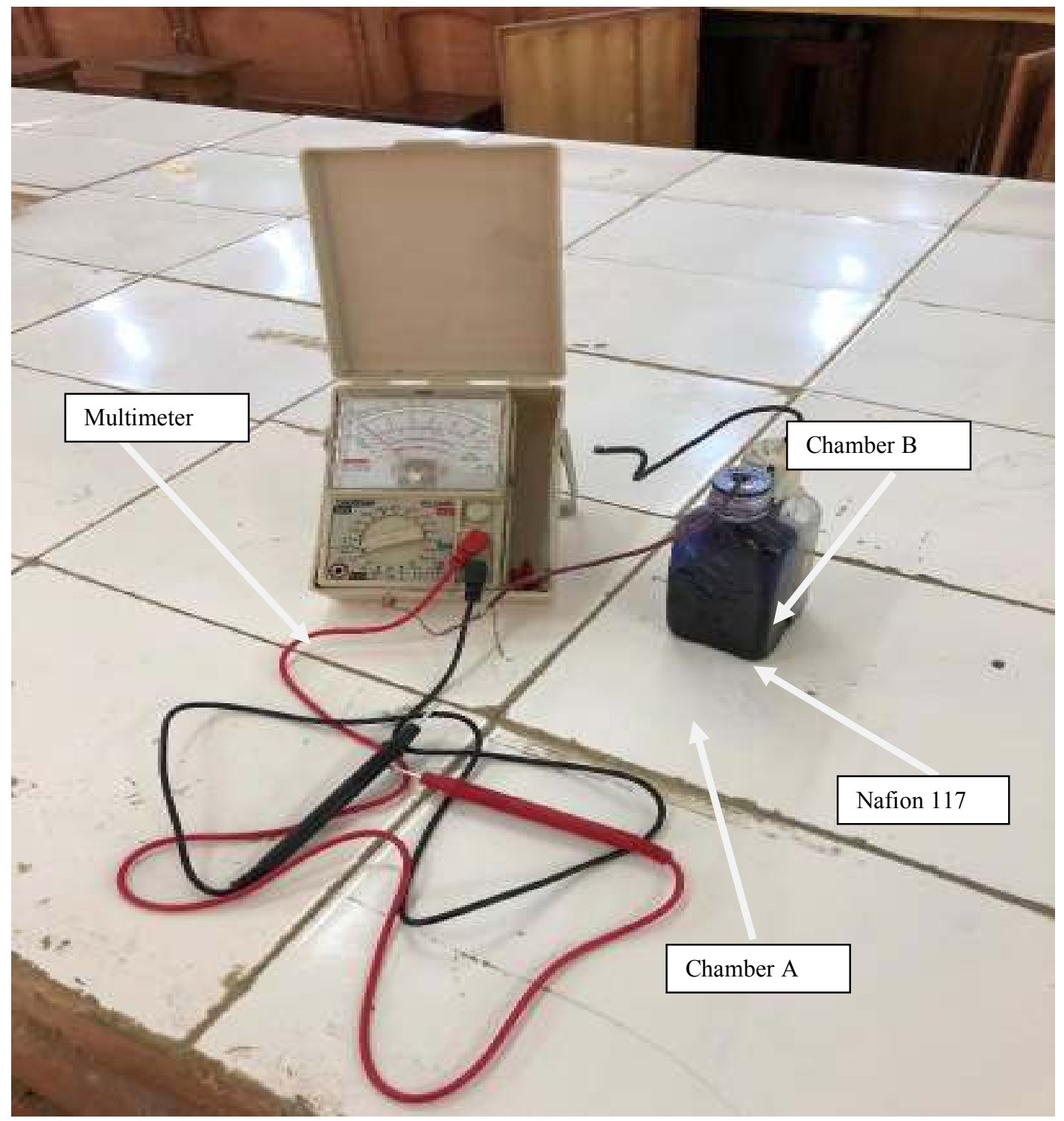

Plate 2: Two Chamber MFC design separated by Nafion

Maintenance of pure isolated yeast: Isolated yeasts were grown on agar slopes of sterile yeast extract peptone dextrose (YEPD) medium containing: 0.5 yeast extract (Lab M), 0.5 bacteriological peptone (Lab M), 0.3 ammonium sulfate (Merck), 0.3 potassium di-hydrogen phosphates (Merck), 2 glucose (Sigma-Aldrich), and 1.5 agar (Lab M). The agar slopes was streaked and incubated at $37^{\circ} \mathrm{C}$ for 48 hours. Slopes were stored at $4^{\circ} \mathrm{C}$ and sub-cultured every 6 months. The Analytical profile index (API) also, molecular characterization of the same isolates as done which revealed their identity as Candida tropicalis, Saccharomyces cerevisiae, Candida albicans and Geotrichum candidum. Electrophoresis gel of the amplified ITS gene from these isolates revealed that Candida tropicalis has 540 base pair; Candida albicans has 600 base pair, Geotrichum candidum 650 base pair and Saccharomyces cerevisiae with 630 base pair Figure 1
Bioelectricity production by the isolates (Yeasts)

The rate of bioelectricity generation by the various isolates was investigated. The isolates were used singly as agent for bioelectricity production. They were also used in different combinations and as a consortium. These experiments were done using the 2 chambered MFC (Logan et al., 2006) with the proton exchange membrane (Nafion 117) as described above.

\section{Bioelectricity production of isolates in continuous culture modules}

Bioelectricity generation from yeast isolates in continuous culture modules was done using the $\mathbf{2}$ chambered MFC with Nafion 117. For the continuous culture experiment, the inoculums were added to the production chamber at 24 hourly intervals. An automated machine (data logger), that records the voltage generated at a set time was attached to the production chamber. It recorded the electrical voltage generated and stored the same on a 2- gig memory card which was later retrieved and analyzed. 
Bioelectricity production of isolates in Stacked MFCs configurations

Different MFCs were stacked together in series and parallel configurations and the rate of electricity generation was monitored by using the 2 chambered MFCs with proton exchange membrane (Nafion 117).

\section{Serial configuration}

This was done according to the method described by William and Tim (2005). Eight different MFCs were connected together in series with the cathode of a preceding MFC being connected to the anode of the succeeding one. The cathode of the last MFC is connected to the anode of the first MFC to form a complete circuit. The energy generated in this experiment is the addition of the electrical energy generated by the individual MFCs connected in the series $(\mathrm{OCV}=$ sum of the voltage of individual cells stacked together in the series).

In serial connection, the MFCs are not independent of each other. Any cut within the circuit will fail the entire system.

\section{Statistical analysis}

The generated data in this study are expressed as means of two values. The data were analyzed with oneway ANOVA using IBM SPSS 20 for multiple comparisons among the different wastes used for bioelectricity generation. Student's test was used for comparisons. $\mathrm{P}<0.05$ was considered statistically significant at a $95 \%$ confidence level.

Results

Using both phenotypic and API, the identified of the different yeasts isolated from the wastewaters used in this study were revealed as Whey processing water (WWW) as Candida tropicalis, Human urine as Candida albicans, Cassava processing water as Saccharomyces cerevisiae, Rabbit dung as Geotrichum candidum. Saccharomyces cerevisiae elicited the highest rate of electricity generation when the isolates were used singly as inoculums for the operation of the MFC, while Geotrichum candidum had the least rate of electricity generation. Startistically, there was no significant difference in the bioelectric generation between a batch culture and continuous culture application of the inoculums in the MFC. Addition of sustrates every twenty-four hour as was done in this study, did not affect the generation of bioelectricity .However, the application of the four isolates in a consortium significantly improved the rate of energy generation $(1.57 \mathrm{~V})$ against what was generated by Saccharomyces cerevisiae (1.08V) (Figure 3 ). Stacking of different MFCs in a series configuration significantly improved the rate of voltage to $2.42 \mathrm{~V}$ 
Table 1 Morphological, cultural and biochemical characteristics of yeasts isolates

\begin{tabular}{|c|c|c|c|c|}
\hline \multirow[t]{2}{*}{ Characteristic } & \multicolumn{4}{|l|}{$\begin{array}{l}\text { Yeast } \\
\text { isolates }\end{array}$} \\
\hline & 1 & 2 & 3 & 4 \\
\hline Colour & Cream & Cream & Cream & Cream \\
\hline Shape & Oval & Oval & Oval & Oval \\
\hline Germ tube test & +ve & + ve & + ve & + ve \\
\hline Lactophenol blue & + ve & + ve & $+\mathrm{ve}$ & + ve \\
\hline Urease & $+\mathrm{ve}$ & + ve & -ve & -ve \\
\hline Catalase & $+\mathrm{ve}$ & $+v e$ & -ve & + ve \\
\hline $\begin{array}{l}\text { Oxidase } \\
\text { Sugar Fermentation }\end{array}$ & $-v e$ & -ve & $+\mathrm{ve}$ & + ve \\
\hline D-Galactose & + & + & + & + \\
\hline Cycloheximide & - & - & + & + \\
\hline D-Saccharose & $\overline{+}$ & $\overline{+}$ & + & + \\
\hline N-Acetyl-Glucossamine & - & + & + & + \\
\hline Lactic acid & $\overline{+}$ & + & + & + \\
\hline $\mathrm{L}$-arabinose & _ & + & + & _ \\
\hline D-Celiobiose & - & + & + & $\overline{+}$ \\
\hline D-Raffinose & $\overline{+}$ & + & + & _- \\
\hline D-Maltose & + & + & + & $\overline{+}$ \\
\hline D-Trehalose & + & + & + & + \\
\hline Potassium 2-Keto Gluconate & - & + & - & + \\
\hline Methyl a D- Gluconate & + & + & - & + \\
\hline D Sorbitol & - & + & $\overline{+}$ & + \\
\hline XYL & - & + & + & + \\
\hline D- Ribose & - & - & + & - \\
\hline Glycerol & - & $\overline{+}$ & + & - \\
\hline L-Rhamnose & - & + & + & - \\
\hline Palatinose & $\overline{+}$ & + & + & $\overline{+}$ \\
\hline Erythritol & _ & + & _ & - \\
\hline D-Melibiose & - & _ & - & - \\
\hline Sodium Glucuronate & - & $\overline{+}$ & $\overline{+}$ & - \\
\hline D-Melezitose & - & + & _ & $\overline{+}$ \\
\hline Potassium Gluconate & - & + & $\overline{+}$ & + \\
\hline Levulinic acid & - & _ & _ & _- \\
\hline D- Mannose & - & $\overline{+}$ & $\overline{+}$ & $\overline{+}$ \\
\hline D- lactose & - & + & - & _- \\
\hline D-innositol & - & - & $\overline{+}$ & - \\
\hline Glucosamine & $\overline{+}$ & $\overline{+}$ & + & $\overline{+}$ \\
\hline Escolin ferric citrate & 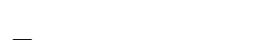 & + & + & 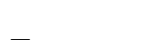 \\
\hline GLN & - & + & + & $\overline{+}$ \\
\hline Probable identity & $\begin{array}{l}\text { Saccharomyces } \\
\text { Cerevisiae }\end{array}$ & $\begin{array}{l}\text { Candida } \\
\text { albicans }\end{array}$ & $\begin{array}{l}\text { Geotrichum } \\
\text { candidum }\end{array}$ & $\begin{array}{l}\text { Candida } \\
\text { Tropicalis }\end{array}$ \\
\hline
\end{tabular}




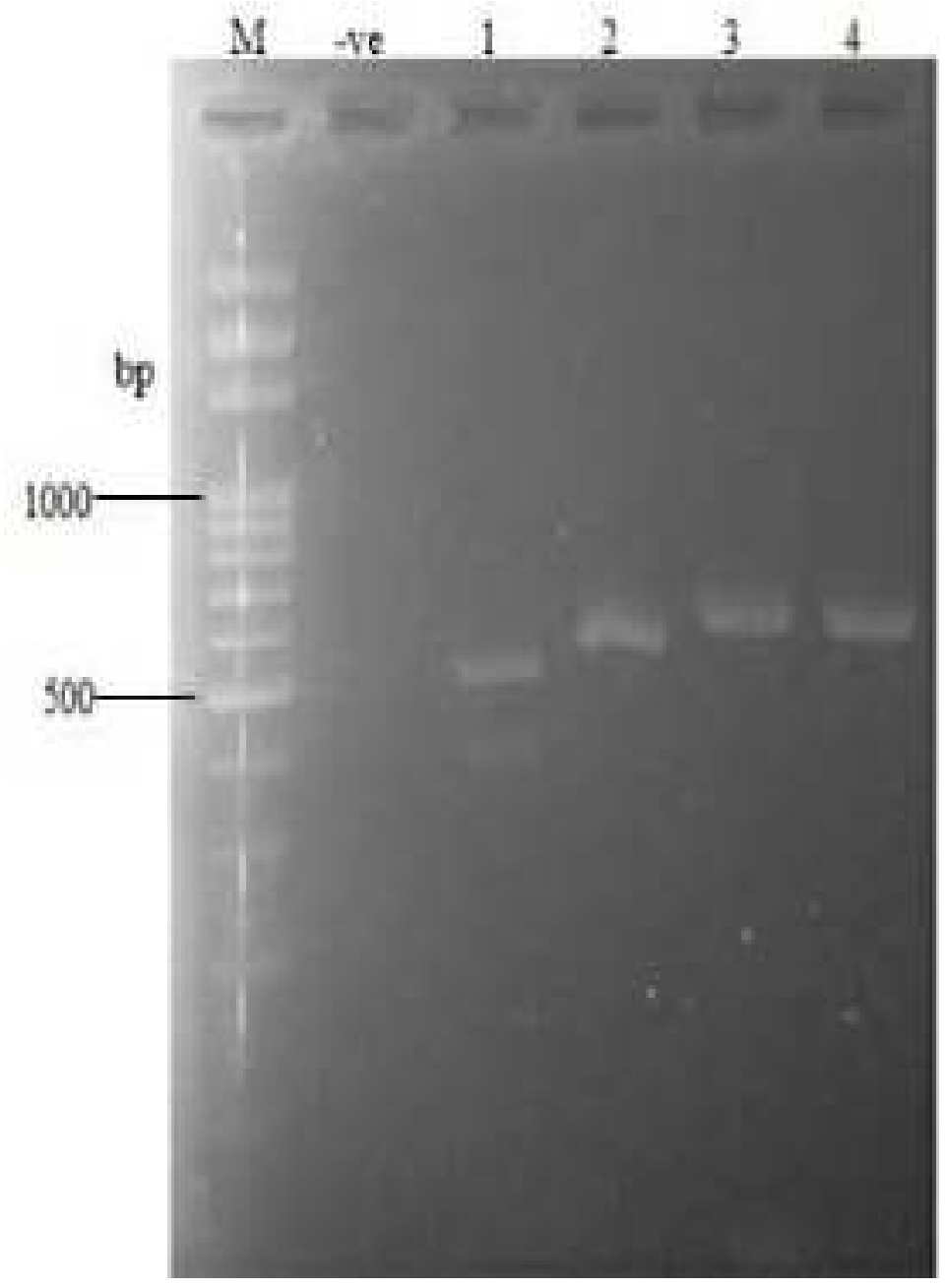

Figure1: Electrophoresis gel of Yeast isolates sample (1) Candida_tropicalis (2) Candida albicans (3) Geotrichum candidum and (4) Saccharomyces cerevisiae 


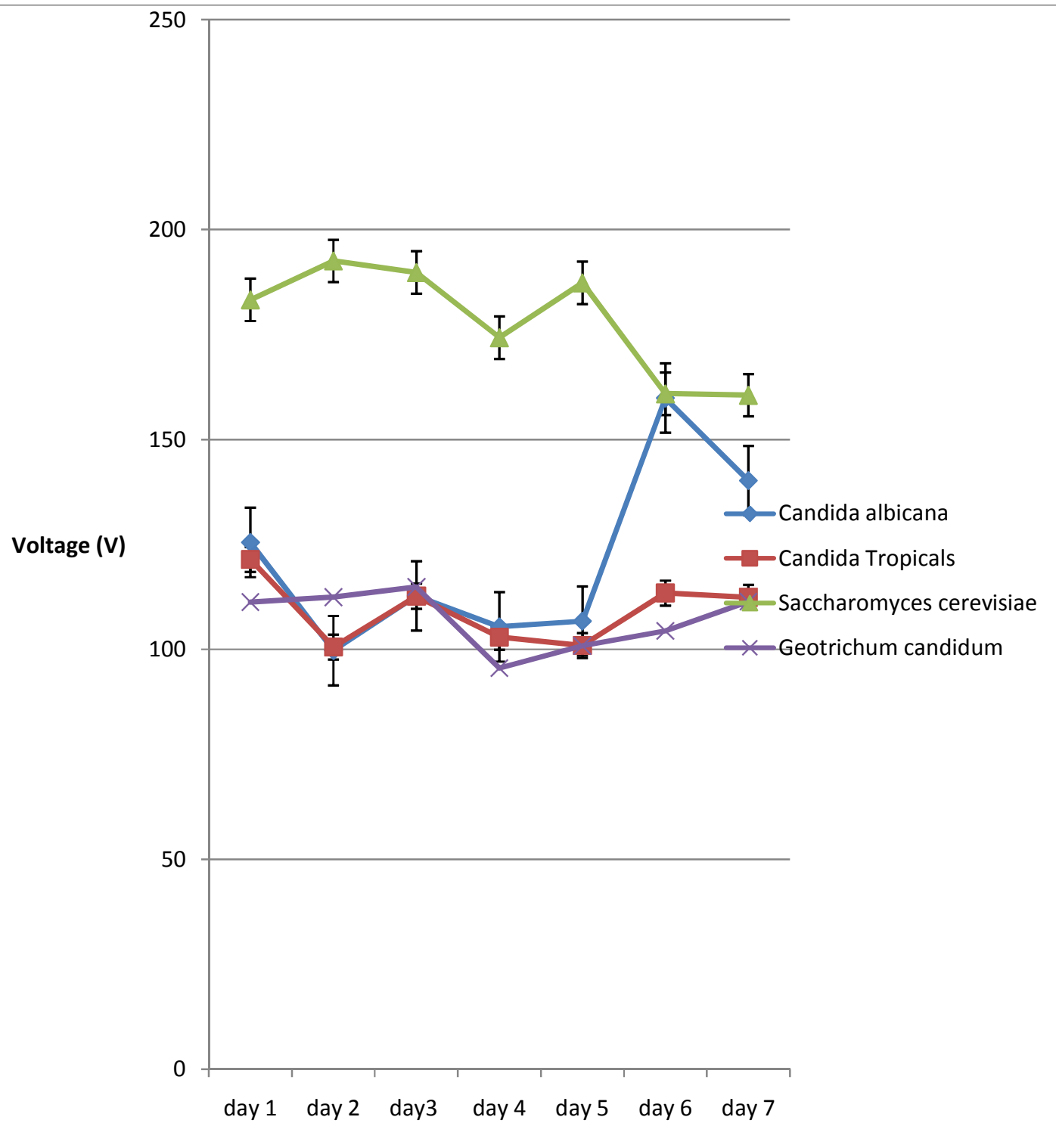

Figure 2: Bioelectricity production of different yeasts in MFCs 


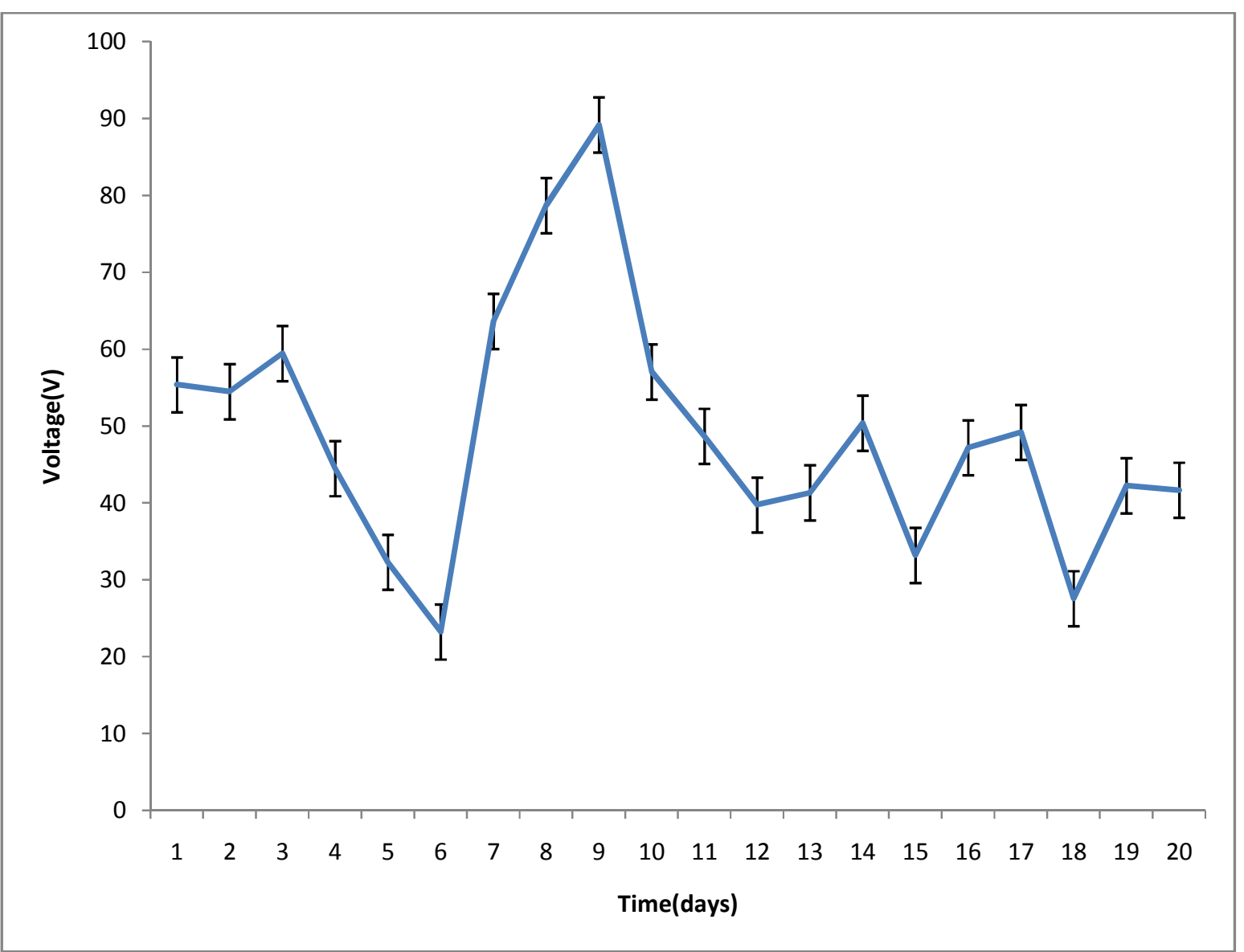

Figure 3: Bioelectricity productions of Saccharomyces cerevisiae in continuous mode on MFC design with Nafion 117 using cassava processing wastewater as substrate 


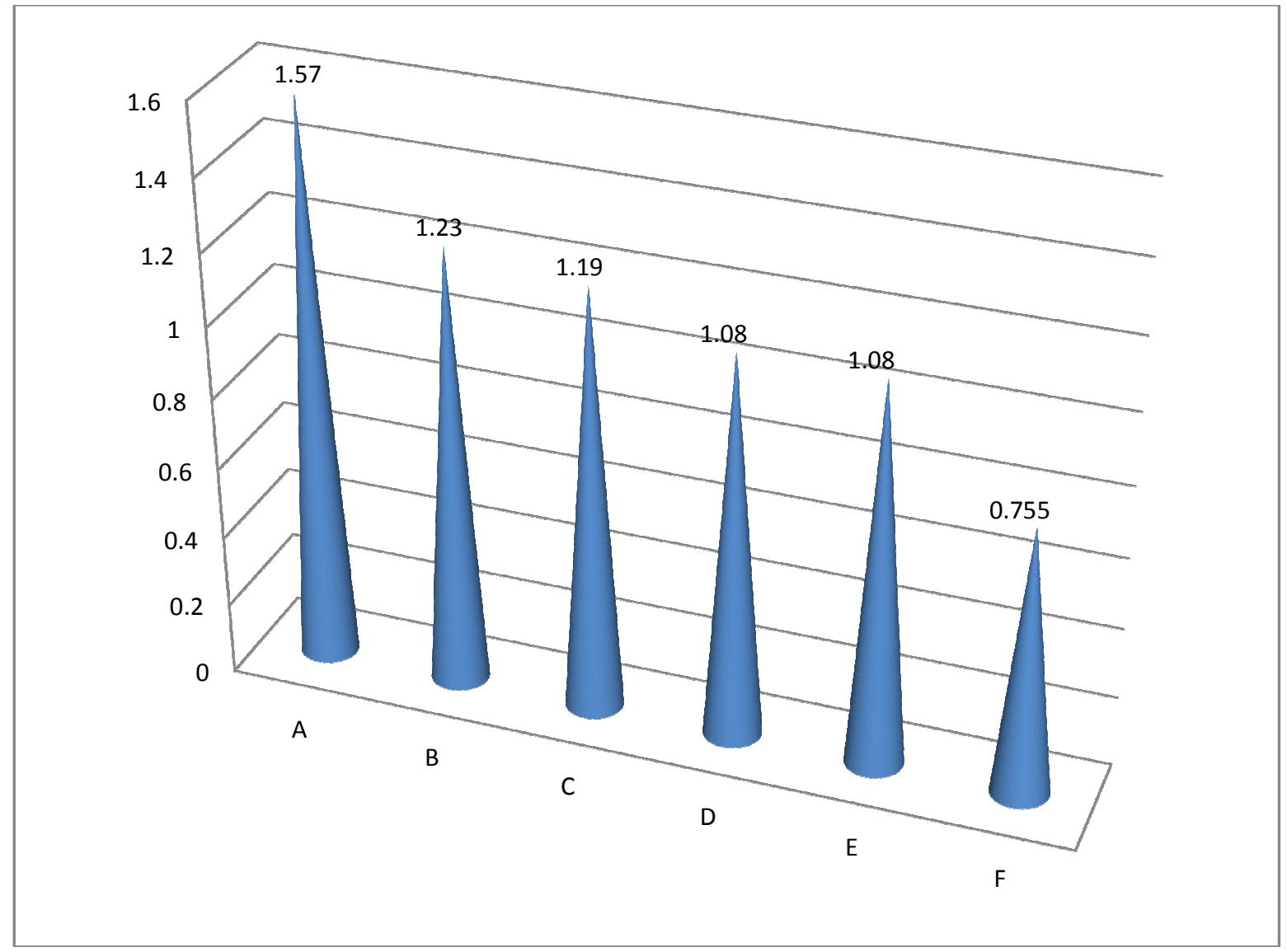

Figure 4: Synergetic effect of bioelectricity production of yeast in consortium

KEY

$\mathrm{A}=$ Candida albicans, Geotrihum candidum and Saccharomyces cerevisiae and C. tropicalis

$\mathrm{B}=$ Candida albicans, Geotrihum candidum and Saccharomyces cerevisiae

$C=$ Candida albicans, Geotrihum candidum and C. tropicalis

$\mathrm{D}=$ Candida albicans and Geotrihum candidum

$\mathrm{E}=$ Saccharomyces cerevisiae, $\mathrm{F}=$ Water

\section{DISCUSSION AND CONCLUSION}

The identification of the isolates was confirmed by the Analytical profile index (API ID 32 C) as, Candida tropicalis, Candida albicans, Geotrichum candidum and Saccharomyces cerevisiae respectively. Similar isolates were identified from the work carried out by Anna-Grepp et al., (2013), which revealed different Candida species and Saccharomyces cerevisiae when two traditional products were fermented. Evaluation of whey waste waste, rabbit dungs, cassava processing waste water and human urine as a substrate for microbial generation of bioelectricity reveals that cassava waste water has great potential for bioelectricity generation. Cassava is a root crop that is very rich in carbohydrate, it is therefore believed that its waste-water will be rich in carbohydrate based compounds which could have served as carbon source for the growth of the microbial cells. This could possibly account for the high electrical energy generated by it compare to the other wastes used in this study. The finding in this study is in agreement with the report of
Olaoye et al., (2018), Agarry et al., (2016) and Kaewkannetra et al.,(2011) who used cassava wastewater to generate bioelectricity. They recorded maximum bioelectricity yield of $0.750 \mathrm{mV}, 1.771 \mathrm{mV}$, and $0.275 \mathrm{mv}$ respectively in there studies using cassava wastewater as their substrates. Adekunle and Raggavan (2017) also used cassava peels extract as a substrate in an MFC and generated maximum voltage of $0.687 \mathrm{mV}$. Saccharomyces cerevisiae generated as high as $1.074 \mathrm{~V}$ in this study, but the work done reviewed by Yolina- Hubenova, et al., (2015) when yeasts were utilized as biocatalysts, the range of bioelectricity got was between 20 to $2440 \mathrm{~mW} / \mathrm{m}^{2}$. There was no significant difference in the bioelectric generation between a batch culture and continuous culture application of the inoculums in the MFC. Continuous addition of inoculums every twenty-four hour as was done in this study, did not affect the generation of bioelectricity but when yeasts were combined in a consortium, there was a synergetic effects among the strains of yeast for bioelectricity generation, it was 
observed that the synergetic effect depends on the types of yeast combined together

Result obtained in this study on the effect of different catholyte materials (Methylene blue, neutral red and potassium ferric cyanide) on the rate of generation of electricity show that there is no significant difference among them. However, Gunawardena et al. (2008) observed improved performance in the rate of electricity generation when Methylene blue and potassium ferric cyanide were used as electron mediators, generating an open circuit voltage of $383.6 \pm 1.5 \mathrm{mV}$. This result indicated that yeast can generate bioelectricity like others prokaryotes but they generated better when used with catholyte such as Neutral red which serves as an electron acceptor in the cathode. Yeasts as microorganisms could be said to be non-pathogenic, easily manipulated, easily cultivated and highly stable. They are dimorphic yeasts and temperature tolerance making them good microbes for study in a eukaryotic microbial fuel cell. The microbial bioelectricity technology is still in an early stage of development, but shows great promise as a new method for electricity generation.

\section{REFERENCES}

Adekunle A. and Raghavan V., 2017. Evaluation of the suitability and performance of cassava waste (peel) extracts in a microbial fuel cell for supplementary and sustainable energy production. Waste Management and Research. 35(1): 47-55.

Agarry, S. E., Gghenejoboh, K. M., and Solomon, B. O., 2016. Bioelectricity production from cassava mill effluents using microbial fuel cell technology. Nigerian journal of Technology. Vol 35, No 2: 329-336.

Anna, G., Kalliopi, R., Wilfrid, P., Joseph, H., Lene, J.,Mogens, J., and Luca, C., 2013. Yeast dynamics during spontaneous fermentation of mawè andtchoukoutou, two traditional products from Benin.International Journal of Food Microbiology. 165: 200-207.

Davis, F., and Higson, S. P. J., 2007. Biofuel cells: Recent advances and applications. Biosensors and Bioelectronics. 22 (7): 1224-1235.

Gunawardena, A., Fernando, S. D., and Braasch, D. A., 2008. Performance analysis of a bio fuel cell based on Lactate Dehydrogenase.In 2008 Providence, Rhode Island, June 29-July 2, 2008 (p. 1).American Society of Agricultural and Biological Engineers.

Haslett, N. D., 2012. Development of a eukaryotic microbial fuel cell using Arxula adeninivorans (Doctoral dissertation, Lincoln University).

Huang, L., Zeng, R. J., and Angelidaki, I., 2008. Electricity production from xyloseusing a mediator-less microbial fuel cell. Bioresource technology, 99(10): 4178-4184.

Kaewkannetra, P., Chiwes, W., and Chiu, T., 2011. Treatment of cassava mill wastewater and production of electricity through microbial fuel cell technology. J.Fuel. 90(8). DOI: 10.1016.

Logan, B. E., Cheng, S. L., 2006. Operational parameters affecting the performance of Mediator less Microbial Fuel Cell MFC. 327-331

Logan, B. E., 2009. Exoelectrogenic bacteria that power microbial fuel cells. Nature Reviews Microbiology. 7(5):375

Logan, B. E., and Rabaey, K., 2012. Conversion of wastes into bioelectricity and chemicals by using microbial electrochemical technologies. Science. 337(6095):686-690.

Olaoye, R. A., Afolayan, O. D., Idowu, T. A., and Olayinka, S. A., 2018. Evaluating the Effectiveness of Cassava Wastewater Treatment in a Low Cost Microbial Fuel Cell. Archives of Current Research International.1-9.

William and Tim 2005. The Circuit Designer's Companion $2^{\text {nd }}$ edition.Butterworth-Heinemann Itd. ISBN-13:978-0750663700 ISBN-10: 0750663707.

Yolina, H., Danail, G., and Mario, M., 2015. Enhanced phytatedephosphorylation by using Candida melibiosica yeast-based biofuel cell.BiotechnolLett. DOI 10.1007/s10529-0141571-9 